\title{
Analysis of a Transportation Network with Railway Migration: A Case Study of Champa (C.G.)
}

\author{
Ar. Mohammad Ahtesham ${ }^{1}$, Shubham Yadav $^{2}$, Sonam Vaidya ${ }^{3}$ \\ Department of Urban Planning, University Teaching Department,Chhattisgarh Swami Vivekanand Technical University, Bhilai \\ Chhattisgarh,491107 \\ Corresponding Author E- mail: ar.ahtesham @ outlook.com ${ }^{1}$; yshubham0819@gmail.com ${ }^{2}$,sonamvd31@ gmail.com ${ }^{3}$
}

\begin{abstract}
Transportation Network gives proficient street transportation methodologies have recently become a functioning research area. Efficient transportation of users to/from congested traffic zones is one of the main difficulties of the users. A transportation-network analysis is presented here and is applied on a town ring road network that envelops a significant network intersections, cardon line and large motorized and non-motorized movement conflicts. The presented study firstly examines the impacts applied by network at major intersections, and secondly, presents contextual analysis of railway migration into the town transport network. The significance of this study is evidently clear in traffic congestion situations or in road design considerations in which the impact of correlation of transport network-intersections must be pre-requisitely known. The aim of the study is to extend the results of this analysis to be applied for evacuation analyses for other zones with similar conditions or in other congested towns in which correlated intersections in the transport network have a significant presence that must be included in the real-life analysis of a transportation network.
\end{abstract}

Key Words - Transportation Network, O-D Study, Cardon Survey, Intersection Study, Railway Migration.

Broad Area - Urban Planning, Transportaion Planning

Sub- Area - Transportation Network Planning

\section{Introduction}

It is recognized that the increase in traffic congestion needs to be addressed through an integrated multi-modal transport system. The savings to the society in facilitating a shift to public transport or non-motorized transport can be significant, particularly in urban peak congested conditions. This may be enhanced through enhancements to the service provided by public transport and non-motorized transport. Improvements to public transport may be considered through a number of roads including improving vehicle efficiency, integration of transport modes, reduction of the cost of service, reductions in travel times and in comfort for passengers. A traffic study is a detailed examination and analysis of a transportation system and network supported by data collection. A study starts with the identification and definition of a transportation problem including network and its infrastructure, followed by data collection and analysis. A study is typically performed to explore a specific aspect of, or question about, a transportation network. Transportation studies serve to quantify the extent of a transportation problem or to provide an analysis of a proposed transportation solution.

Champa (M) is an area of approximately $18.57 \mathrm{sq}$. kms. of Janjgir-Champa district. Total geographical area of the district is 3852.75 square 
kms. as reported by the Surveyor General of India. The research study identifies the progression of the transportation characteristics, network and its sustainable development for the municipality of Champa.

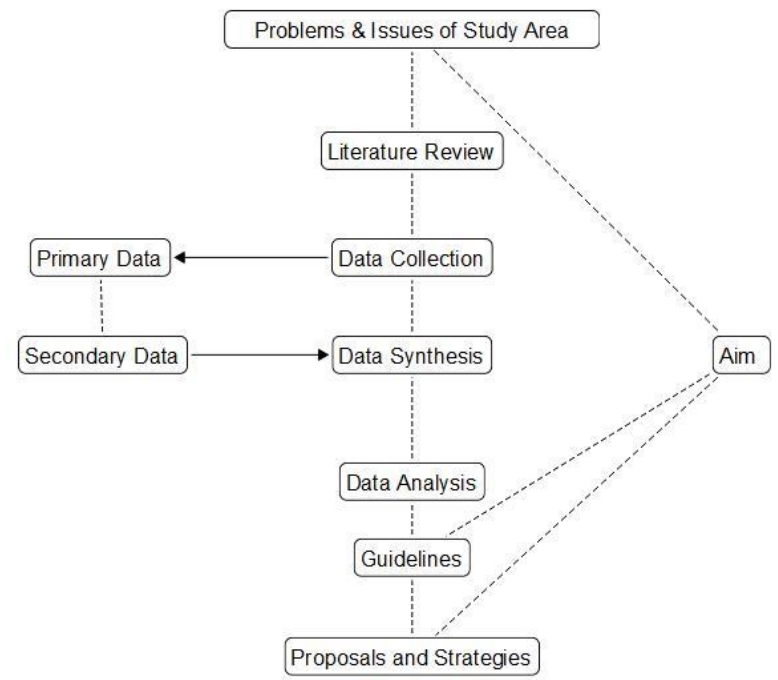

Fig. 1 Shows the Methodology followed.

\subsection{Study Area Profile}

Champa is a city and municipality in JanjgirChampa district in the Indian state of Chhattisgarh. Janjgir-Champa district is situated between $21^{0} 6^{\prime}$ to $22^{0} 4^{\prime}$ North latitudes and between $82^{0} 3^{\prime}$ to $83^{0} 2^{\prime}$ East longitudes in Chhattisgarh state. Height of the district from sea level is $294.4 \mathrm{mts}$. And that of Champa town is $253 \mathrm{mts}$. Topographically, the district is bounded by Raigarh district in the East, Bilaspur district in the West, Korba and Bilaspur district in the North and Raipur \& Raigarh district in the South. Total geographical area of the district is 3852.75 sq. kms. and Champa city is 18.52 sq. kms. as reported by the Surveyor General of India. The district Janjgir-Champa is situated in the uppercenter part of the State. Janjgir, the district headquarters of the district is the city of Maharaja Jajawalya Dev of Kulchury dynasty. It is at a distance of $43 \mathrm{kms}$. from Bilaspur, which is the divisional headquarters of the district. Also,
Champa is famous for its Kosa Silk, Gold and Brass Metal work. This town is situated on the banks of Hasdeo river. Figure 2 shows the JanjgirChampa district map.

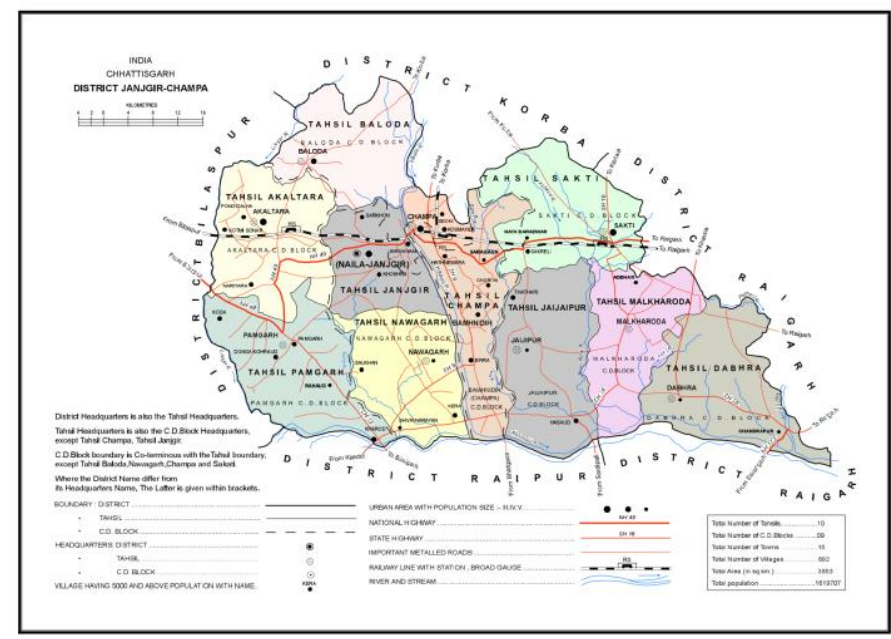

Fig 2 Janjgir-Champa District Map

The detailed development plan for city Champa is showed in Figure 3.

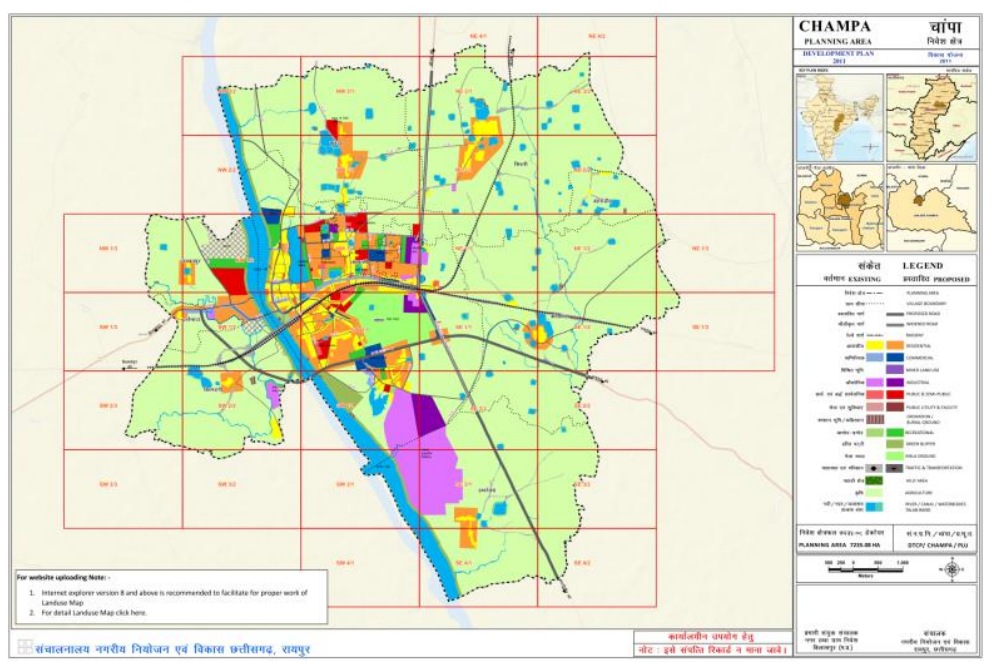

Fig 3 Champa Development Plan

The Champa city in the below picture, comprises the population of 45,256 and total number of households counts to 9,843 spread over the area of 18.57 sq. kms. Champa Municipality comprises of 21 wards according to Census of India, 2011. However, current number of wards in the Champa 
municipality is 27 wards as depicted in the Figure

3.

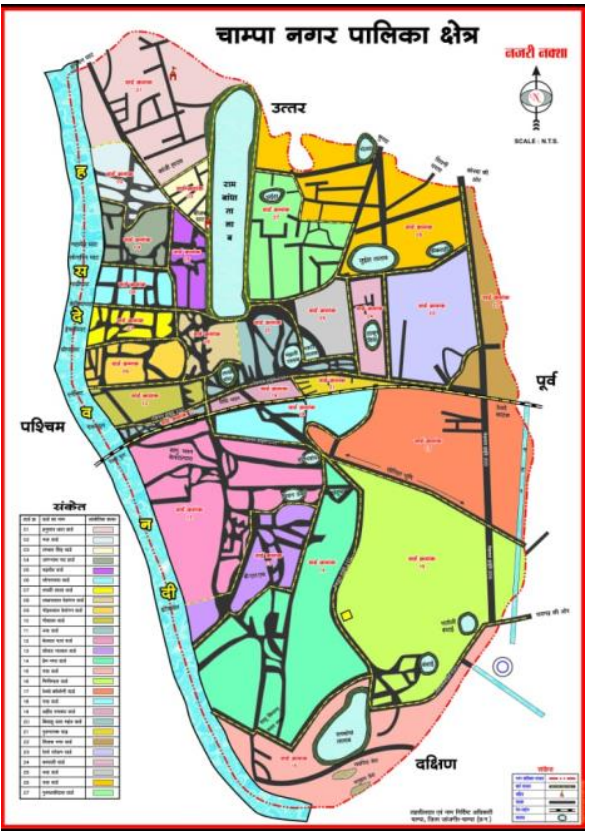

Fig. 3 Champa city Ward Map

The details of the road network are depicted schematically in the Figure 4 providing the arterial, sub-arterial, collector roads, major intersections, railway lines, National Highway understanding within the research area.

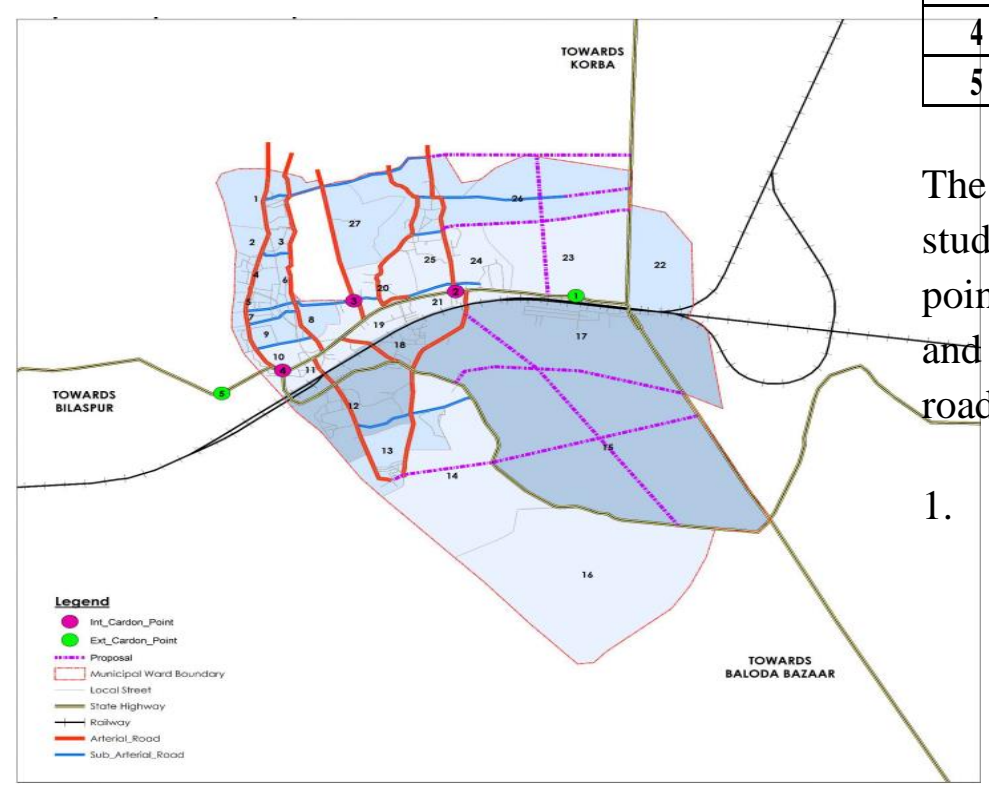

Fig. 4 GIS Map of the Champa Research Area

\section{Primary Data}

\subsection{Traffic Scenario of the city.}

Cordon Count are made at the perimeter of an enclosed area (CBD, shopping center etc.). Vehicles or persons entering and leaving the area during a specified time period are counted. These provide useful information about trips from and to external zones. For large study area, internal cordon-line can be defined and surveying can be conducted. The objective of the survey is primarily to collect the origin and destination zones. The Cardon points are picked in accordance, carrying highest passenger car units (PCU) during peak hours. Lack of traffic management, congestion

increased at inner Cardon points. The detailed analysis of the survey conducted are presented in the table below w.r.t. Figure 4.

\begin{tabular}{|c|c|c|c|c|}
\hline $\begin{array}{c}\text { Location } \\
\text { Code }\end{array}$ & Location & $\begin{array}{c}\text { Direction / } \\
\text { No. of Roads }\end{array}$ & Cardon & Duration \\
\hline $\mathbf{1}$ & Railway Station & 2 Directions & Cardon & Morning :07:00 am - 08:00 am \\
\hline $\mathbf{2}$ & Barpai Chowk & 3 Directions & External & Morning :07:00 am - 08:00 am \\
\hline $\mathbf{3}$ & New Bus Stand & 4 Directions & Internal & Morning :07:00 am - 08:00 am \\
\hline $\mathbf{4}$ & Birghani Chowk & 3 Directions & External & Morning :07:00 am - 08:00 am \\
\hline $\mathbf{5}$ & Barrier Chowk & 3 Directions & Duration & Morning :07:00 am - 08:00 am \\
\hline
\end{tabular}

The traffic composition using the traffic volume study was conducted at the designated cardon points (internal \& external) to frame the issues and undertand the traffic flow analysed using the road map and inventory.

1. Railway Station Chowk. 


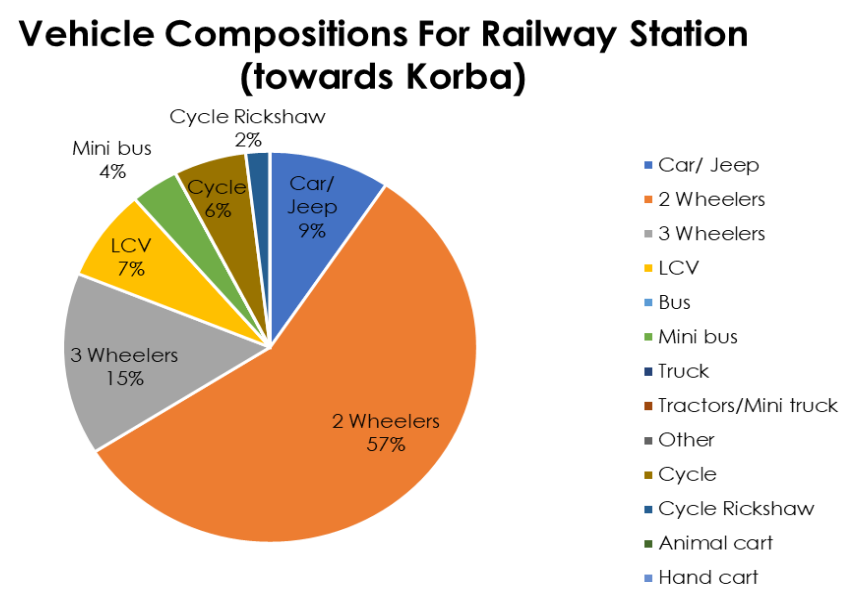

Vehicle Compositions For Railway Station (towards Janjgir)

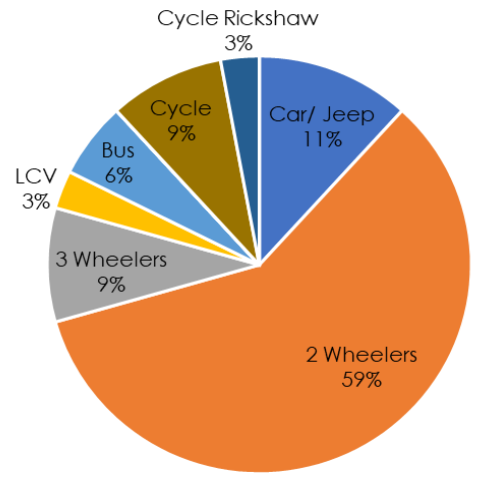

2. Barpali Chowk:

\section{Vehicle Compositions For Barpali Chowk(towards Gurunanak Marg)}
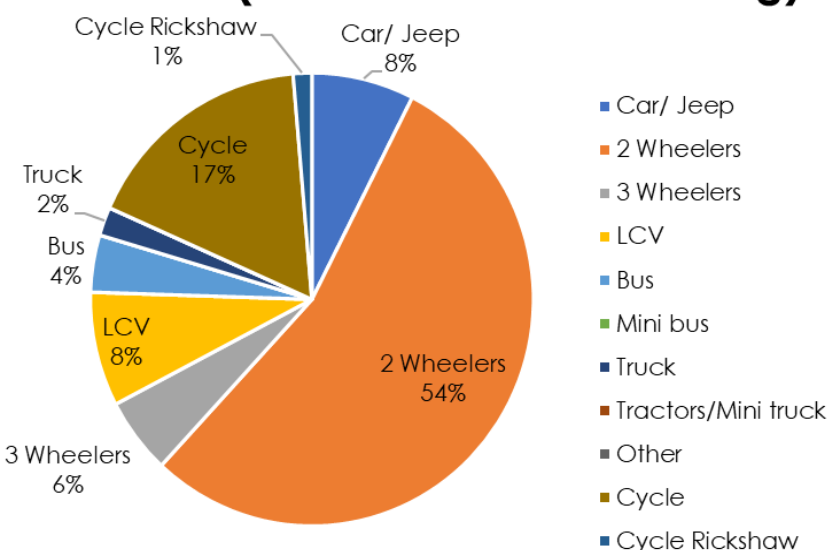

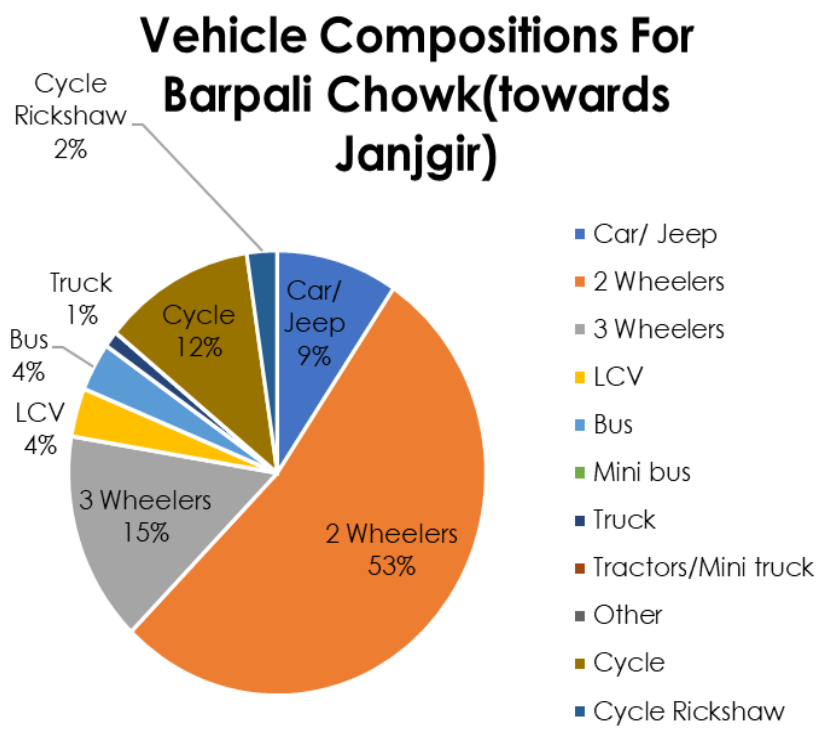

\section{Vehicle Compositions For Barpali Chowk(towards Railway Station)}

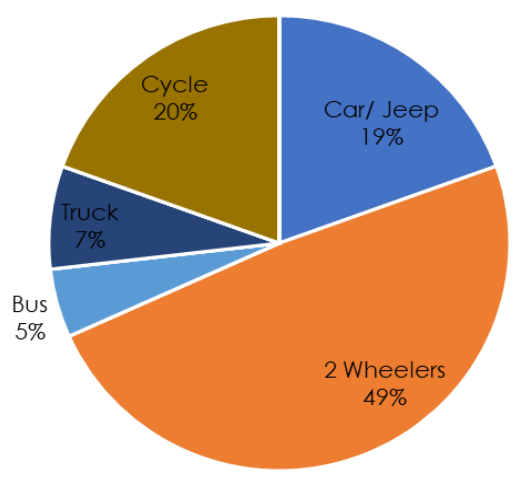

- Car/ Jeep
- 2 Wheelers
- 3 Wheelers
= LCV
- Bus
- Mini bus
- Truck
- Tractors/Mini
truck
- Other
- Cycle

3. Bus Stand Chowk

Vehicle Compositions For Bus Stand Chowk (towards MMR College Rd.)

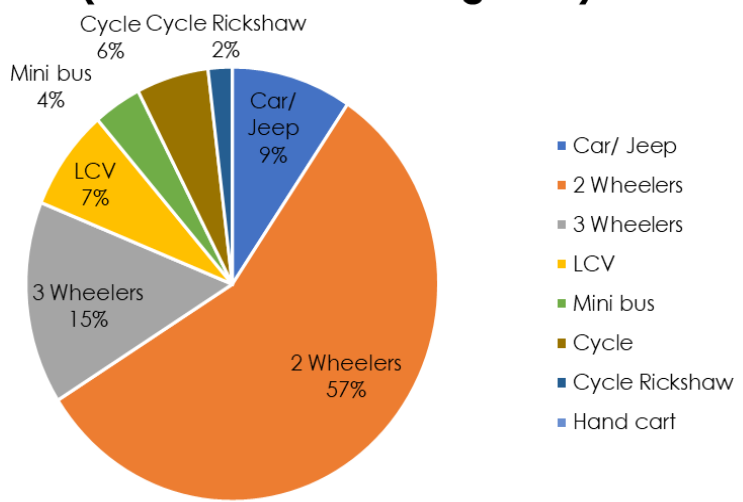




\section{Vehicle Compositions For Bus Stand Chowk (towards Railway Station)}

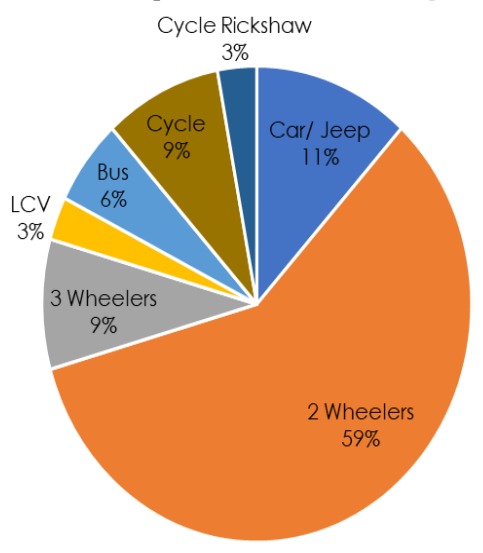

- Car/ Jeep

$\because 2$ Wheelers

$\because 3$ Wheelers

$\because \mathrm{LCV}$

- BUS

- Mini bus

- Tractors/Mini truck

- Cycle

- Cycle Rickshaw
4. Birghani Chowk

\section{Vehicle Composition for Birghani Chowk(towards Janjgir)}

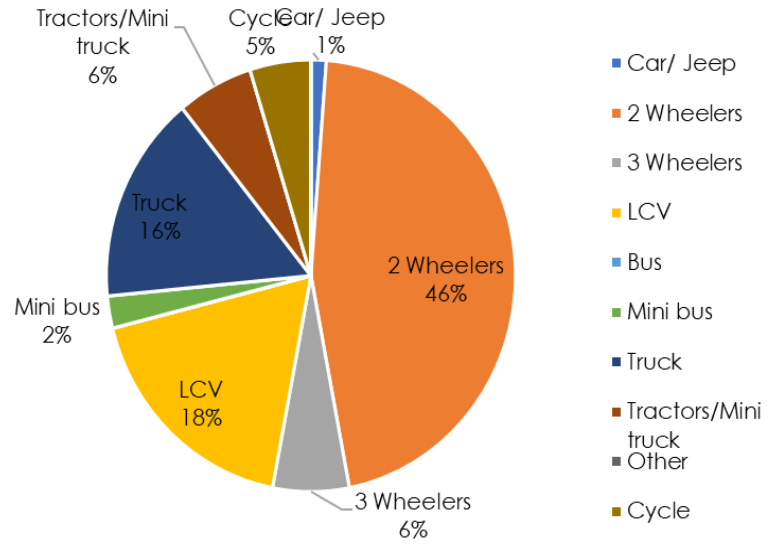

\section{Vehicle Composition for Birghani Chowk(towards Crusher)}

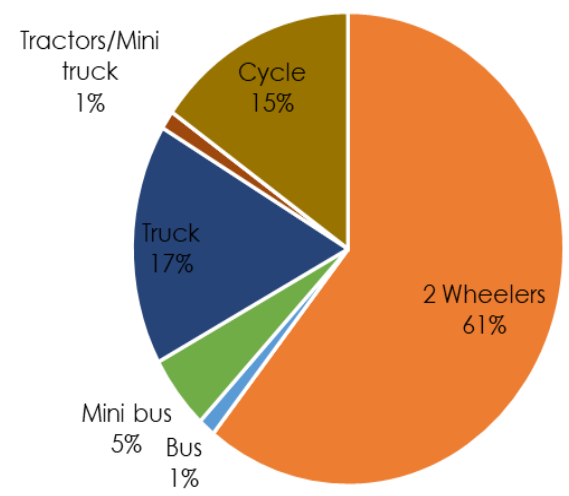

- Car/ Jeep

$\because 2$ Wheelers

$\llbracket 3$ Wheelers

= LCV

$\approx$ Bus

- Mini bus

- Truck

- Tractors/Mini

truck

- Cycle

\section{Vehicle Composition for Birghani Chowk(towards Champa)}

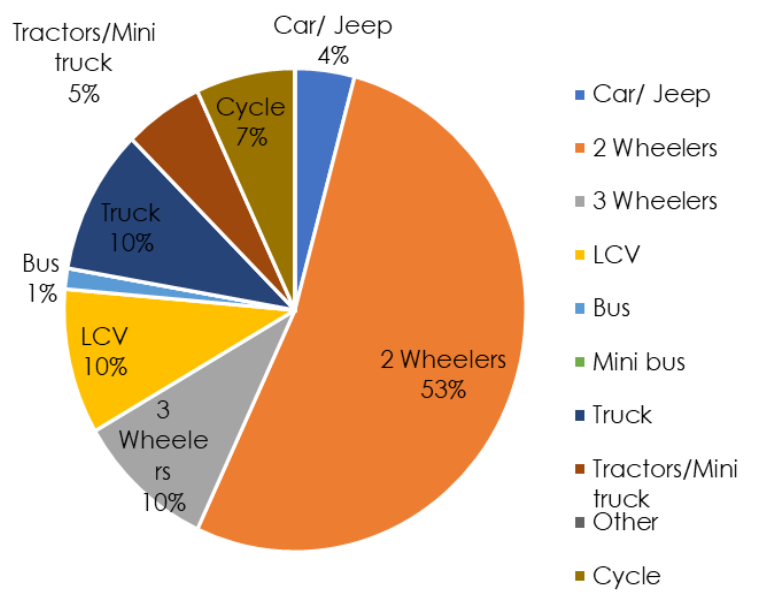

\subsection{Origin-Destination (O-D) Study.}

The OD matrix is calculated based on the traffic volume and flow and people's survey to frame the traffic flow and the usability of the road networks within the city along the cardon lines. The detailed summary is depicted in Table 1 which shows the travel demand (purpose wise). And the based on the intersections study the O-D matrix is carved, which is shown in Table 2.

Table 1. Travel Demand (purpose Wise)

\begin{tabular}{|c|c|c|c|}
\hline S. No. & Purpose & $\begin{array}{c}\text { No. of } \\
\text { Trips }\end{array}$ & Percentage \\
\hline 1 & Home based work & 451 & $44 \%$ \\
\hline 2 & Home based education & 348 & $34 \%$ \\
\hline 3 & Home based business & 154 & $15 \%$ \\
\hline 4 & Home based other & 72 & $7 \%$ \\
\hline & Total & 1024 & $100 \%$ \\
& & & \\
\hline
\end{tabular}

\subsection{Traffic study Findings}

- Railway Station, Birghani Chowk are the busiest junctions in Champa; this intersection makes a 
way to outer bypass road, Korba road and Janjgir road.

- Barpali Chowk, New Bus Stand are the internal nodes connecting the core city and outskirts and are center of purpose-based trip generations.

Table 2 - OD matrix

\begin{tabular}{|c|c|c|c|c|c|c|}
\hline $\mathrm{O} / \mathrm{D}$ & 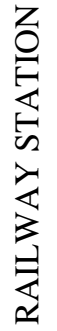 & 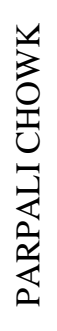 & 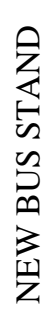 & 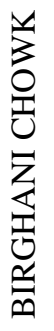 & 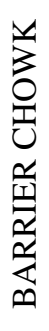 & 吾 \\
\hline $\begin{array}{l}\text { RAILWAY } \\
\text { STATION }\end{array}$ & & 19 & 17 & 12 & 10 & 66 \\
\hline $\begin{array}{c}\text { BARPALI } \\
\text { CHOWK }\end{array}$ & 16 & 4 & 6 & 9 & 3 & 38 \\
\hline $\begin{array}{c}\text { NEW BUS } \\
\text { STAND }\end{array}$ & 11 & 16 & 2 & 2 & 15 & 46 \\
\hline $\begin{array}{c}\text { BIRGHANI } \\
\text { CHOWK }\end{array}$ & 13 & 2 & 8 & 5 & 11 & 39 \\
\hline $\begin{array}{c}\text { BARRIER } \\
\text { CHOWK }\end{array}$ & 10 & 2 & 2 & 6 & 4 & 24 \\
\hline Total & 58 & 43 & 35 & 34 & 43 & 213 \\
\hline
\end{tabular}

\subsection{Railway Migration}

Champa Junction $282.80 \mathrm{~m}$ above Sea Level Track: Quadruple Electric Line Departures from Champa Junction (3 PFs) Jn. Pt.: Korba/BilaspurJharsuguda) Zone: SECR/ Division: Bilaspur \# No. of Halting Trains: 76 Champa railway station lies on the Tatanagar-Bilaspur section of HowrahNagpur-Mumbai line as well as on GewraChampa line which connect to Korba.

The railway travel data was gathered from the station manager from the year 2013 - 2018 to frame the baseline of the floating population and monthly season tickets (MST) passengers. As Champa is the railway junction connecting Howrah Mumbai line to Korba.

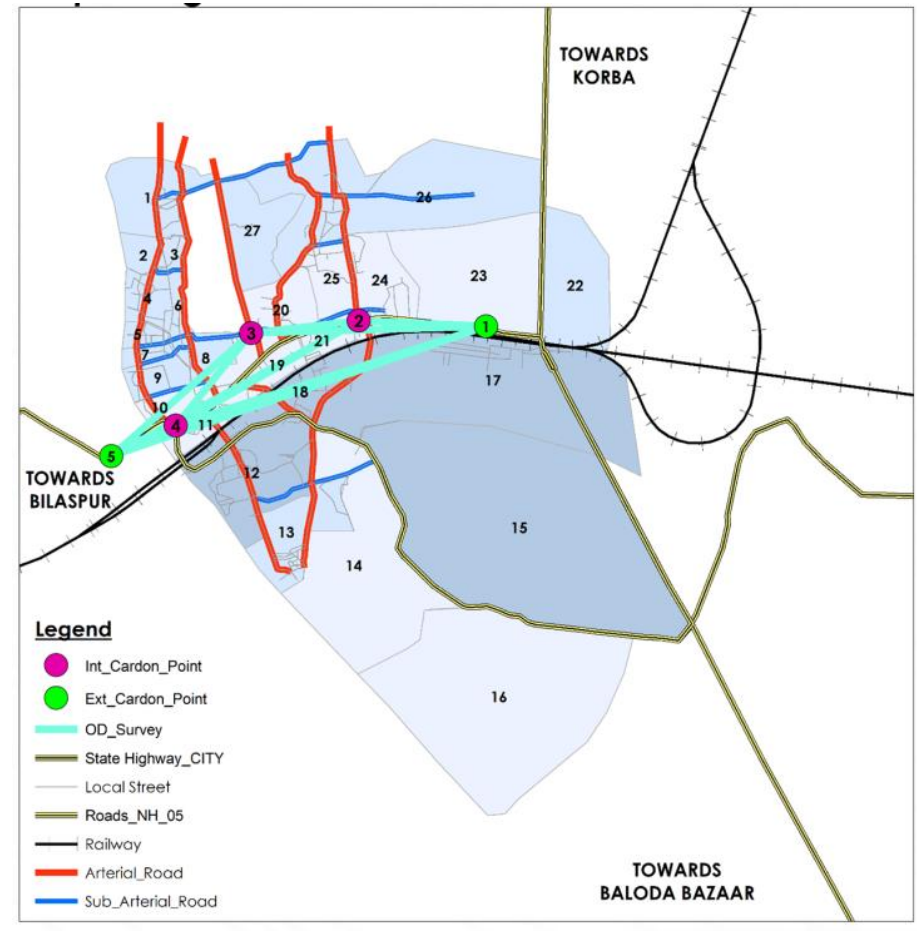

Fig. 5 Origin - Destination at Cardon Line Map

While studying the daily commute data of the railway, the following observations were found:

- Baseline set at 13 lakhs passengers commute annually.

- $\quad$ MST passengers found to be at base of 3.3 lakhs on annual basis.

- $\quad$ Declining in passengers since year 2017.

- $\quad$ Same declination seen in MST passengers

- Variable rise on floating population seen till year 2017 .

\begin{tabular}{|c|c|c|c|}
\hline Year & Passengers & MST & $\begin{array}{c}\text { Percentage of } \\
\text { MST }\end{array}$ \\
\hline 2013 & 1541492 & 348000 & $23 \%$ \\
\hline 2014 & 1458904 & 367525 & $25 \%$ \\
\hline 2015 & 1556094 & 409455 & $26 \%$ \\
\hline 2016 & 1440875 & 410280 & $28 \%$ \\
\hline 2017 & 1672129 & 404700 & $24 \%$ \\
\hline 2018 & 1375555 & 377100 & $27 \%$ \\
\hline
\end{tabular}




\subsection{Railway Migration Findings.}

Around $20 \%$ fall seen in passengers in previous years. Declination result of infrastructure development near Railway Station. Migrating Population as daily commuters to and from Bilaspur. Majority of daily commuters to be seen as educational employees. High demand of public transport system to be deployed.
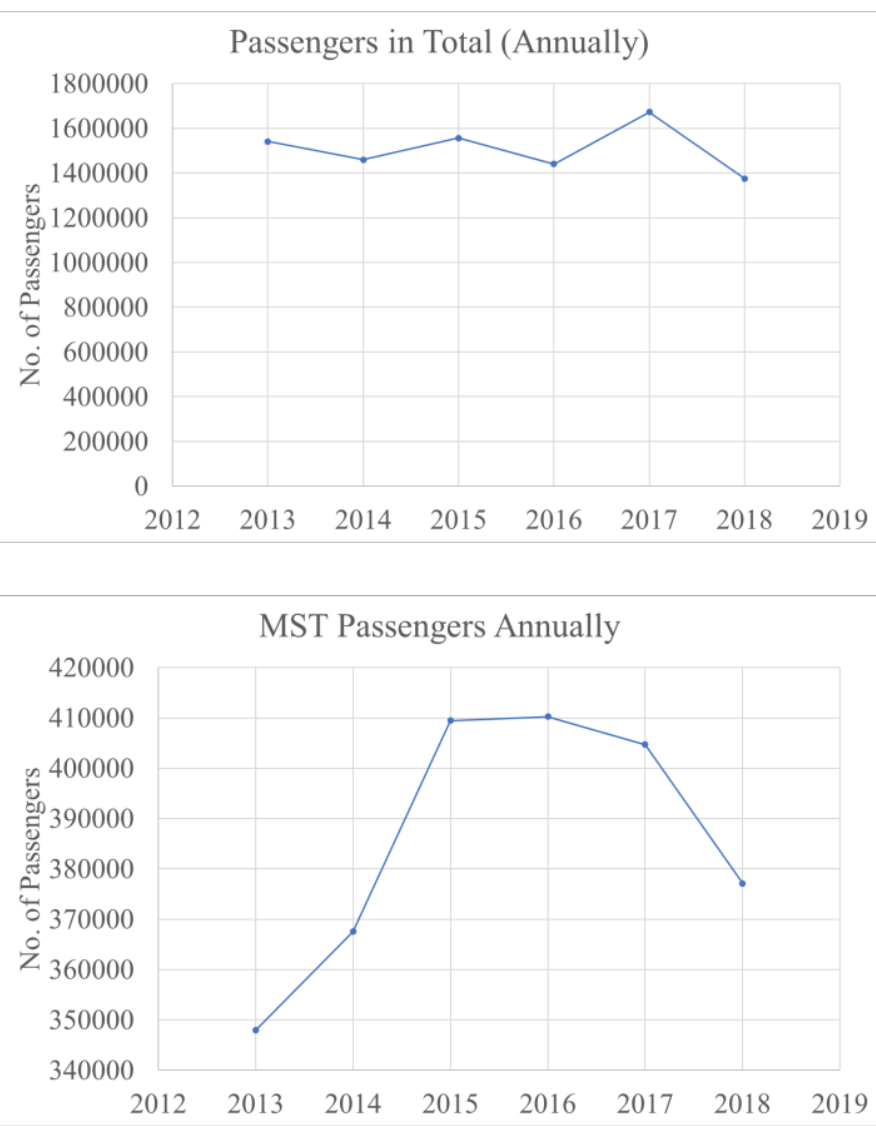

\section{Proposals and ReCOMMENDATIONS}

The study conducted in the Champa city shows that the alarming issues to be addressed to maximize the transportation network and impact of the migration and floating population in the city.

1. e-Rickshaws running without any specific routes.

2. No dedicated local inter-city bus service.

3. Lack of Public Transport by Government.
4. No safety considerations.

5. Lack of Bus Stops within the city.

6. More Congestion due to absence of stoppages.

7. No dedicated rickshaw stands.

8. Absence of Parking bays.

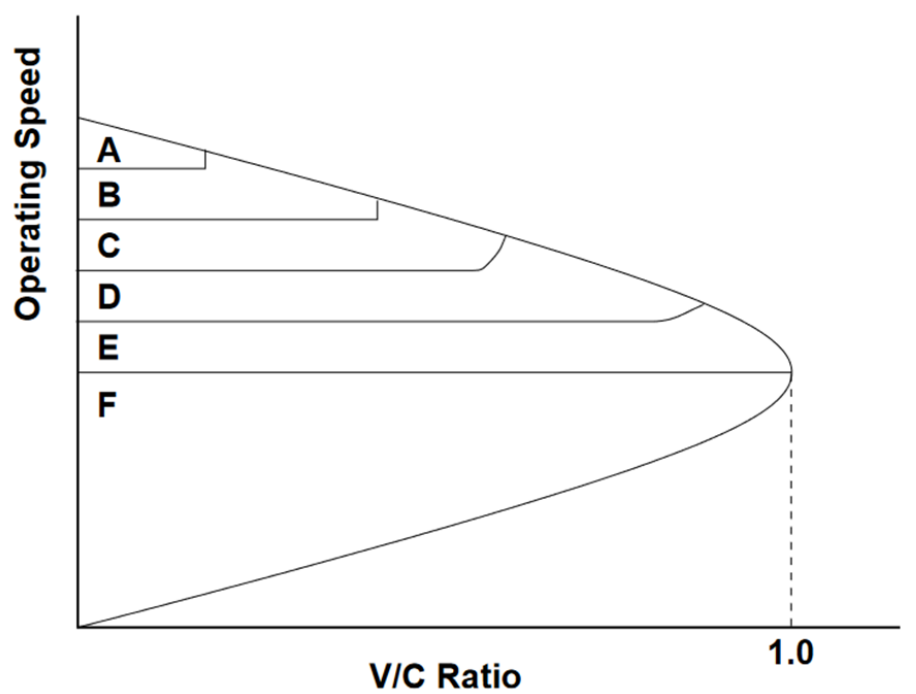

Fig. 6 Illustrates the quality of Level-of-Services (A to F) and the various operating conditions.

\begin{tabular}{|c|c|c|c|l|}
\hline LOS & Quality & $\begin{array}{c}\text { Speed } \\
\text { (kmph) }\end{array}$ & V/C & \multicolumn{1}{|c|}{ Description } \\
\hline A & Free-Flow & 80 & 0.6 & $\begin{array}{l}\text { High Level of } \\
\text { Physical \& } \\
\text { Psychological } \\
\text { Comfort }\end{array}$ \\
\hline B & $\begin{array}{c}\text { Reasonable } \\
\text { free-flow }\end{array}$ & 70 & 0.7 & $\begin{array}{l}\text { Reasonable Level of } \\
\text { Physical \& } \\
\text { Psychological } \\
\text { Comfort }\end{array}$ \\
\hline C & $\begin{array}{c}\text { Near free- } \\
\text { flow }\end{array}$ & 60 & 0.8 & $\begin{array}{l}\text { Local Deterioration } \\
\text { Possible with } \\
\text { Blockages }\end{array}$ \\
\hline D & $\begin{array}{c}\text { Medium } \\
\text { flow }\end{array}$ & 50 & 0.85 & $\begin{array}{l}\text { Non-recoverable } \\
\text { Local Disruptions }\end{array}$ \\
\hline E & $\begin{array}{c}\text { At } \\
\text { Capacity } \\
\text { flow }\end{array}$ & 40 & 0.9 & $\begin{array}{l}\text { Minor Disturbances } \\
\text { Resulting Breakdown }\end{array}$ \\
\hline F & $\begin{array}{c}\text { Congested } \\
\text { flow }\end{array}$ & 15 & 1.0 & $\begin{array}{l}\text { Break Down of Flow } \\
\text { Capacity Drops }\end{array}$ \\
\hline
\end{tabular}




\section{Conclusions}

Throughout this paper, for uncongested transport networks O-D matrix is estimated viz. two-step methodology was proposed. Firstly, a travel distribution model was calibrated using both zonal socio-economic and existing traffic counts to obtain an initial OD matrix. Secondly, the estimated initial matrix was improved by using traffic counts collected from additional links of railway migration on the network. This creates a key opportunity to bring together transportation \& migration, \& continue to incorporate different performance measures into decision-making about arterial roads design, balancing the complementary \& competing demands of transportation to migration. For the same, refer to the intervention and retrofitting described in Figure 6 along with the following Measures to Reduce Traffic Congestion in the city.

\section{Short Term Measures:}

- Alter the timings of the junction traffic signals and review the traffic and pedestrian phases to ease congestion at certain times of the day.

- Alteration of signal timings during off peak hour period.

- Movement of heavy commercial vehicles should be avoiding at day time and allow at night time.

\section{Long Term Measures:}

- Channelization of junction like providing free left on both sides of the junction.

- Extra widening of carriage width by reducing the footpath width.

- Underpass should be provided from Barpali Chowk towards PIL block.

- Models like modal split, travel time demand can be generated.

\section{Conflict of Interest}

The authors declare no conflict of interest.

\section{References}

[1] District Census HandBook - CHHATTISGARH https://censusindia.gov.in/2011census/dchb/Chhattisgar hA.html

[2] Champa ward Map and details. - https://janjgirchampa.gov.in/en/

[3] South East Central Railway https://secr.indianrailways.gov.in/view_section.jsp?lang $=0 \& \mathrm{id}=0,7$

[4] Transportation Planning, 8.2., URDPFI Guidelines, 2014. Ministry of Urban Development

[5] Visual surveys / Reconnaissance survey, URDPFI Guidelines, 2014.

[6] Preparation of existing land use maps, 7.7.2.2., URDPFI Guidelines, 2014. Ministry of Urban Development.

[7] TOD Development Control Norms, 8.2.15.5., URDPFI Guidelines, 2014. Ministry of Urban Development.

[8] Champa Development Plan, Directorate of Town and Country Planning, Chhattisgarh, http://tcp.cg.gov.in/vikasyojna/JANJGIRCHAMPA/Champa.htm

[9] James H Banks.Introduction to transportation engineering. Tata Mc-Graw Hill, 2004.

[10] W R McShane and P R Roger.Traffic Engineering. Prentice Hall Publication, 1990.

[11] C. S Papacostas.Fundamentals of Transportation Engineering. Prentice-Hall, NewDelhi, 1987. 